Acta vet. scand. $1968,9,41-49$.

From the Department of Surgery, Veterinary College of Norway, Oslo.

\title{
EPIDURAL ANAESTHESIA IN YOUNG PIGS, DOSAGE IN RELATION TO THE LENGTH OF THE VERTEBRAL COLUMN
}

\author{
By \\ Anders Strande
}

The pig is the domestic animal in which congenital malformations are most often found. Many of these malformations necessitate surgical intervention, for example hermaphroditism, cryptorchism and inguinal hernia. According to Albertsen (1951) the incidence of hermaphroditism in the pig found in Danish slaughter-houses increased from 0.035 to $0.6 \%$ from 1933 to 1950. In Norway hermaphroditism has become quite a problem for many pig breeders. The veterinary practitioner is therefore frequently asked about operations for this condition. The pigs in question are usually young, weighing from 15 to $40 \mathrm{~kg}$. The question then arises of which type of anaesthesia should be used. Inhalation anaesthesia and parenteral barbiturate anaesthesia have been used. Epidural anaesthesia provides another alternative. In the literature several suggestions are found for the dosage of epidural anaesthetics in pigs. Frank (1953) recommended $1 \mathrm{ml}$ anaesthetic per $4.5 \mathrm{~kg}$ pig. Wright \& Hall (1961) as a guiding principle recommended $10 \mathrm{ml} 2 \%$ procain or $5 \%$ tutocain epidurally in the lumbosacral space to pigs weighing up to $40-50 \mathrm{~kg}$. With reference to Frank's dosage, these authors state: "A point to be considered in the pig is - up to what weight should his computation be employed, for in fat adults fat often represents a considerable proportion of body weight". Westhues \& Fritsch (1960) recommended a dose of 5-10 $\mathrm{ml}$ of a $4 \%$ novocain or a $2 \%$ tutocain solution to a pig weighing $50-150 \mathrm{~kg}$ to obtain anaesthesia caudal to the curvature of the ribs. Bollwahn (1963) has empirically reached a dosage of $2 \%$ Hostacain $\AA$ of 
$0.57 \mathrm{ml}$ per $10 \mathrm{~cm}$ body length measured from the external occipital protuberance to the 1st coccygeal vertebra. Of 203 operated pigs the anaesthesia was good in $80 \%$, satisfactory in $12 \%$ and unsatisfactory in $8 \%$ of the pigs. Most of the pigs were adults. The need for a more accurate dosage of epidural anaesthetics based on experiments is felt. This investigation was carried out in an attempt to solve this problem.

\section{MATERIAL AND METHODS}

Seventy pigs were used, varying in length from 40 to $99 \mathrm{~cm}$, measured with a measuring tape from the external occipital protuberance to the 1st coccygeal vertebra, and varying in weight from 6 to $65 \mathrm{~kg}$. The injection technique in young pigs was the same as in the dog, as it is not difficult to palpate the 2 tuber coxae and the processus spinosus of the last lumbar vertebra.

To get an idea of the size of the lumbosacral space it was dissected free in 5 destroyed pigs ranging in length from 69 to $77 \mathrm{~cm}$ and in weight from 22 to $33 \mathrm{~kg}$. The dissection was carried out by removing all the tissue dorsal to the lumbosacral column. The interarcuate ligament was removed both in the L7/S1 and the $\mathrm{S} 1 / \mathrm{S} 2$ space. Using a measuring instrument with $1 / 10 \mathrm{~mm}$ accuracy the greatest diameter of the space was measured in the median plane and in the transverse plane with the lumbosacral column markedly flexed. The S1/S2 space appeared to be rather large and was measured in the same way, naturally without any flexion of the spine.

The needle used in puncturing the epidural cavity was $6-8 \mathrm{~cm}$ long with a diameter of $1.2-1.3 \mathrm{~mm}$ and a short point. There was a short pause after puncture of the epidural space to see whether cerebrospinal fluid or blood came out, before the solution was injected. About $20 \mathrm{~min}$. after preliminary premedication with $0.5 \mathrm{mg}$ Combelen ${ }^{\circledR}$ (a phenothiazine derivative) per $\mathrm{kg}$ i.m., a mixture of a radiopaque contrast medium and a local anaesthetic was injected through the lumbosacral space. This was injected with the pig in the lateral position on the radiographic table. Two ml was injected at a time, and a radiograph taken immediately afterwards with a latero-medial direction of the $x$-ray beam. The smallest pigs were given a total of $4 \mathrm{ml}$ and the largest up to $10 \mathrm{ml}$. The injection needle and the syringe were continuously connected to each other and kept at right 
angles to the pigs back. This was achieved by making a pad of cotton wool between the radiographic table and the syringe. The radiopaque contrast medium used was Urografin ${ }^{\circledR}(3,5$ diacetylamino - 2,4,6 - triiodobenzoic acid) and the local anaesthetic $2 \%$ Xylocain-exadrin $\AA$ (lidocainchlorid + adrenalin). Different relative proportions of Urografin and Xylocain-exadrin were tried such as: $45 \%$ Urografin and $2 \%$ Xylocain-exadrin, in equal volumes, 1 part $60 \%$ Urografin and 2 parts $2 \%$ Xylocain-exadrin or 2 and 3 parts of each respectively. One part $76 \%$ Urografin and 2 parts $2 \%$ Xylocain-exadrin was found most satisfactory. It gave a good anaesthesia and the contrast was also satisfactory.

The following procedure was used in interpretation of the radiographs. If the contrast stopped at the same level dorsally and ventrally to the dura, this was indicated by the appropriate name and number of the vertebra in question if this occurred opposite a vertebra. If the contrast stopped opposite an intervertebral disc this was indicated as the transition between 2 adjacent vertebrae, for example L4/L5. When the graphs were made, the number of the most cranial of the 2 vertebrae was used, in this case L4. If the contrast reached different heights dorsally and ventrally to the dura the place it reached ventrally was noted. The pigs were classified in groups according to the length of their backbone. There was $10 \mathrm{~cm}$ 's difference between each group. In the graphs the vertebrae are numbered from 1 to 23 starting with $\mathrm{T} 1=1$.

\section{RESULTS}

The results sometimes varied considerably among pigs within each length group. The results are presented as graphs (Fig. 1).

T a b le 1. Mean length and weight of the pigs in each group.

\begin{tabular}{rccrr}
\hline $\begin{array}{c}\text { Number } \\
\text { of pigs }\end{array}$ & $\begin{array}{c}\text { Length } \\
\text { group } \\
\text { cm }\end{array}$ & $\begin{array}{c}\text { Mean length of } \\
\text { the pigs in the group } \\
\text { in cm }\end{array}$ & $\begin{array}{c}\text { Weight } \\
\text { variation } \\
\text { in kg }\end{array}$ & $\begin{array}{c}\text { Mean } \\
\text { weight } \\
\text { in kg }\end{array}$ \\
\hline 4 & $40-49$ & 45.2 & $6-10$ & 8.5 \\
13 & $50-59$ & 53.9 & $9-17$ & 12.5 \\
10 & $60-69$ & 64.5 & $15-25$ & 10.0 \\
20 & $70-79$ & 73.4 & $23-43$ & 29.5 \\
15 & $80-89$ & 84.0 & $25-48$ & 39.5 \\
8 & $90-99$ & 93.6 & $47-63$ & 53.5 \\
\hline
\end{tabular}




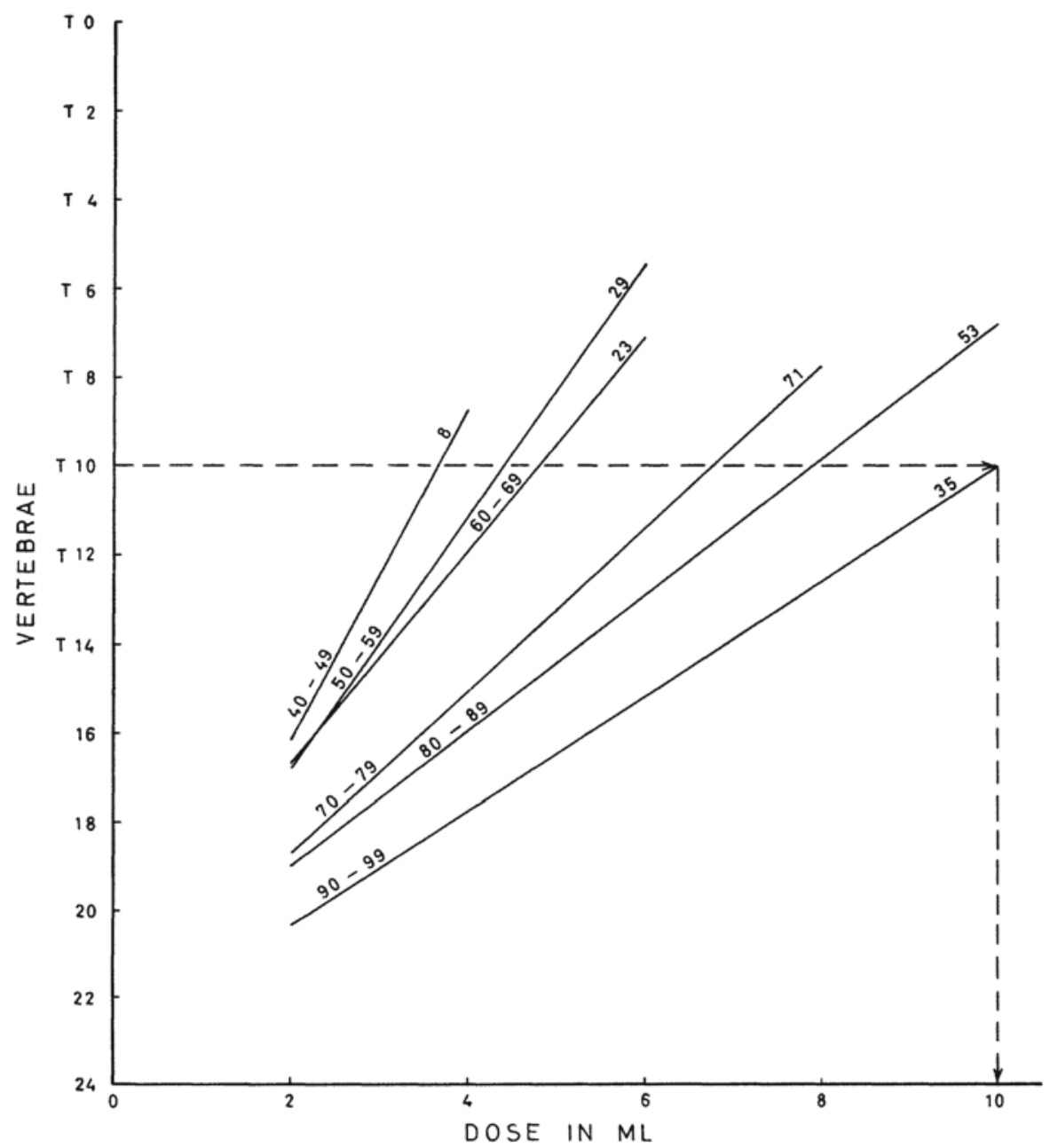

Figure 1. The spread of the epidural anaesthetic in relation to the dose injected. The figures on the lines refer to the length class in $\mathrm{cm}$ and the number of paired observations respectively.

This figure shows the linear regression lines of how far cranially in the epidural space the mixture of contrast medium and anaesthetic solutions reached in relation to the dose injected. The figures on the lines refer to the length class in $\mathrm{cm}$ and the number of paired observations respectively.

A comparison was made between the mean length and the mean weight of the pigs in each group (Table 1).

Radiography showed that there was a great variation in the 
T a b l e 2. Percentage distribution of thoracic and lumbar vertebrae in the pigs.

\begin{tabular}{|c|c|c|c|}
\hline $\begin{array}{l}\text { Total number } \\
\text { of thoracic and } \\
\text { lumbar vertebrae }\end{array}$ & $\begin{array}{l}\text { Number of thoracic/ } \\
\text { lumbar vertebrae }\end{array}$ & $\begin{array}{l}\text { Number } \\
\text { of pigs }\end{array}$ & $\begin{array}{c}\% \\
\text { of pigs }\end{array}$ \\
\hline 21 & $\left\{\begin{array}{l}14 / 7 \\
15 / 6\end{array}\right.$ & $\left.\begin{array}{l}1 \\
9\end{array}\right\} 10$ & 14.3 \\
\hline 22 & $\left\{\begin{array}{l}15 / 7 \\
16 / 6\end{array}\right.$ & $\left.\begin{array}{l}11 \\
36\end{array}\right\} 47$ & 67.1 \\
\hline 23 & $\left\{\begin{array}{l}17 / 6 \\
16 / 7\end{array}\right.$ & $\left.\begin{array}{l}8 \\
5\end{array}\right\} 13$ & 18.6 \\
\hline
\end{tabular}

number of thoracic and lumbar vertebrae from pig to pig. The different combinations found are shown in Table 2.

The lumbosacral space in the pig is rather much larger than in a dog of the same size. In addition the S1/S2 space in the pig could easily be used for epidural injections. This space is about the same size as the L7/S1 space in the dog (Table 3).

One of the 70 pigs died of respiratory paralysis shortly after the last injection. This was a pig weighing $10 \mathrm{~kg}$ and $52 \mathrm{~cm}$ long. The radiograph showed that $6 \mathrm{ml}$ of the radiopaque contrast anaesthetic solution reached T8 dorsally, but to the 2 nd cervical vertebra ventrally. Three of the pigs developed convulsions $2-3$ hrs. after the injection. These pigs were kept under control with mebumal (pentobarbital) intravenously. One of them died.

I addition it shall be mentioned that during the last 6 years this institute purchased more than 1000 pigs suffering from either hermaphroditism, cryptorchism or inguinal hernia. The pigs were used in the teaching programme in surgery for the

$\mathrm{T}$ a b l e 3. The size of the L7/S1 and S1/S2 spaces in pigs compared with the size of the L7/S1 space in dogs of the same size.

\begin{tabular}{lccccc}
\hline Animal & $\begin{array}{c}\text { Length } \\
\text { of the spine } \\
\text { in } \mathrm{cm}\end{array}$ & $\begin{array}{c}\text { Diam. of L7/S1 } \\
\text { space in median } \\
\text { flexed mosition } \\
\text { of the spine }\end{array}$ & $\begin{array}{c}\text { Diam. of L7/S1 } \\
\text { space in trans- } \\
\text { verse plane in } \\
\text { mm max. flexed } \\
\text { position } \\
\text { of the spine }\end{array}$ & $\begin{array}{c}\text { Diam. of } \\
\text { S1/S2 } \\
\text { space } \\
\text { median } \\
\text { plane } \\
\text { in mm }\end{array}$ & $\begin{array}{c}\text { Diam. of } \\
\text { S1/S2 } \\
\text { space } \\
\text { transver- } \\
\text { sal plane } \\
\text { in mm }\end{array}$ \\
\hline $\begin{array}{l}\text { Pig } \\
\text { English } \\
\text { Setter }\end{array}$ & $69-77$ & 17.6 & 24.5 & 14.3 & 17.1 \\
\hline
\end{tabular}


undergratuate veterinary students. Under supervision the students performed the anaesthesia, surgery and aftercare all by themselves. The routine anaesthetic method was premedication with ataraxics followed by epidural anaesthesia. The mortality rate was low, and only in 3 cases the death could be directly attributed to the anaesthesia - a sudden fall in blood pressure with shock and collapse.

\section{DISCUSSION AND CONCLUSION}

Assuming that the anaesthetic must extend up to T10 to obtain sufficient anaesthesia of the ventral abdominal wall in a laparotomy and drawing a horizontal line through T10 in the points of intersection on the different curves, an estimate will be obtained of the mean amount of anaesthetic needed in each length group (Fig. 1). In Table 4 these figures have been recorded and compared with Bollwahn's (1963) suggested dose of $0.57 \mathrm{ml}$ per $10 \mathrm{~cm}$ length.

T a b l e 4. Anaesthetic dose in $\mathrm{ml}$ needed for laparotomy in young pigs.

\begin{tabular}{cccc}
\hline $\begin{array}{c}\text { Length group, } \\
\mathrm{cm}\end{array}$ & $\begin{array}{c}\text { Bollwahn, } \\
\mathrm{ml}\end{array}$ & $\begin{array}{c}\text { Strande, } \\
\mathrm{ml}\end{array}$ & $\begin{array}{c}\text { Strande, dog, } \\
\mathrm{ml}\end{array}$ \\
\hline $40-49$ & & 3.65 & \\
$50-59$ & 2.85 & 4.40 & 2.18 \\
$60-69$ & 3.42 & 4.80 & 3.73 \\
$70-79$ & 3.99 & 6.75 & 4.75 \\
$80-89$ & 4.56 & 8.90 & 6.25 \\
$90-99$ & 5.13 & 10.00 & 8.85 \\
\hline
\end{tabular}

There was a very good agreement between the dose of epidural anaesthetic in young pigs and dogs in the length group from 60 to $99 \mathrm{~cm}$ according to Table 4 . The 2 smallest length groups differed somewhat. In the group $40-49$ there were only 4 pigs so this result is somewhat uncertain. The suggested dose for epidural anaesthetic in dogs recommended by Strande (1968) could be used for pigs - the length varying from 40 to $100 \mathrm{~cm}$. The recommended dose was: In a dog up to $40 \mathrm{~cm} 1 \mathrm{ml}$ is given, after this an additional $1.5 \mathrm{ml}$ is given for every $10 \mathrm{~cm}$ increase in the vertebral column of the pig. 
Because of large individual variations in the penetration of a solution in the epidural space in young pigs, when giving epidural anaesthesia one should always be prepared for deviations from the expected result. With the approximate doses given, the chances of deaths resulting from the anaesthesia should be minimal and also the percentage of insufficient anaesthesia extremely low.

If we look at the results of the experiments carried out with the combination of epidural radiopaque contrast and local anaesthetic, and at the results of operations carried out by inexperienced students on a large number of young pigs, it can be said that epidural anaesthesia combined with premedication with an ataraxic has provided very satisfactory anaesthesia for operations on the abdominal cavity or caudal regions of the body. The anaesthesia is rapid to carry out and the safety margin is large.

In order to examine the varying number of thoracic and lumbar vertebrae, Berge (1949) in the period 1932 to 1942 crossbred a large number of pigs with 20, 21, 22 and 23 thoracic and lumbar vertebrae. He x-rayed the descendents and found that $3.5 \%$ had 20 vertebrae, $37 \%$ had 21 vertebrae, $55 \%$ had 22 vertebrae and $3.8 \%$ had 23 vertebrae. Compared with the figures in Table 2, it seems that a continuously increasing number of pigs have a larger number of thoracic and lumbar vertebrae. The present observations are few, but they give some indication of the general trend.

The large lumbosacral space and the space between the 2 first sacral vertebrae faciliated the induction of the epidural anaesthesia. It can be said it was easier to perform an epidural anaesthesia in young pigs than in dogs. The chance of puncturing the dural sac is supposed to be about the same in the 2 species.

\section{REFERENCES}

Albertsen, K.: Hermafroditisme hos svin. Nord. Vet.-Med. 1951, 3, 849868.

Berge, S.: Svineavl. Grøndahl \& S $\varnothing$ ns Forlag, Oslo 1949.

Bollwahn, W.: Experimentelle und klinische Untersuchungen zur Rückenmarksanaesthesie beim Schwein. Tierärztl. Umsch. 1963, 18, 271-279.

Frank, E. R.: Veterinary Surgery. Burgess Publishing Co, Minneapolis, Minn. 1953, p. 7. 
Strande, A.: Some studies in epidural anaesthesia in the dog. Acta. vet. scand. 1968. In press.

Westhues, M. \& R. Fritsch: Die Narkose der Tiere, Band I, p. 144. Verl. Paul Parey, Berlin \& Hamburg 1960.

Wright, J. G. \& L. W. Hall: Veterinary Anaesthesia. Baillière, Tindall and Cox, London 1961.

\section{SUMMARY}

Using a radiopaque contrast medium and a local anaesthetic injected epidurally in 70 young pigs, measuring $40-100 \mathrm{~cm}$ in length and weighing 6-65 kg, it was investigated how far foreward the anaesthetic penetrated for every $2 \mathrm{ml}$ injected epidurally. As a result of this a simple rule has been formulated for the number of $\mathrm{ml}$ anaesthetic needed for a laparotomy in young pigs. The same dosage schedule used for epidural anaesthesia in dogs recommended by the author Strande (1968) could be used for pigs $40-100 \mathrm{~cm}$ in vertebral column length.

It is pointed out that the large interarcuate space between L7/S1 will facilitate the inducing of epidural anaesthesia.

Records of over 1000 cases of epidural anaesthesia for lapararotomies carried out by inexperienced undergraduate veterinary students are mentioned.

\section{ZUSAMMENFASSUNG}

Epiduralanästhesie bei jungen Schweinen. Dozierung im Verhältnis zur Länge der Wirbelsäule.

Mit Hilfe von Röntgenkontrast und einer Lösung von Lokalanästhetikum epiduralt injiziert wurde an 70 jungen Schweinen mit einer Körperlänge von 40 bis $100 \mathrm{~cm}$ und einem Gewicht von 6 bis $65 \mathrm{~kg}$ festgestellt, wie weit ein Anästhetikum für jede injizierten $2 \mathrm{ml}$ vordringt. Das Ergebnis dieser Untersuchung ist schematisch angegeben worden um zu zeigen, wieviel ml einer Anästhetikumlösung für eine Laparotomie bei jungen Schweinen benötigt werden. Es zeigte sich, dass man bei Schweinen in der Grösse 40-100 cm dieselbe Dosis benutzen konnte wie die, welche vom Verfasser für Hunde (Strande 1968) angegeben worden war.

Die grosse interarcuale Spalte zwischen L7/S1 und S1/S2 erleichtert die Ausführung der Epiduralanästhesie.

Die Ergebnisse von mehr als 1000 Epiduralanästhesien für Laparotomie an jungen Schweinen, von ungeübten Veterinärstudenten ausgeführt, werden beschrieben. 


\section{SAMMENDRAG}

Epiduralanestesi til unge griser, dosering $i$ forhold til lengden av hvirvelsøylen.

Ved hjelp av røntgenkontrast og en oppløsning av lokalanestetikum injisert epiduralt har en på 70 unge griser med kroppslengde $40-100$ cm og vekt fra 6 til $65 \mathrm{~kg}$ konstatert, hvor langt frem en anestesiopp$1 \varnothing$ sning trenger for hver $2 \mathrm{ml}$ en injiserer. Som resultat av dette har en f $\varnothing \mathrm{rt}$ opp en enkel skjematisk huskeregel for, hvor mange ml en trenger av anestesioppløsningen for å foreta en laparotomi på unge griser. Det viste seg, at en kunne bruke den samme dose som forfatteren har angitt til hund (1968) for griser fra 40 til $100 \mathrm{~cm}$ 's lengde.

Den store interarcuale spalte mellom L7/S1 og S1/S2 letter utførelsen av epiduralanestesien.

Det er omtalt resultatene av over 1000 epiduralanestesier for laparotomi på unge griser utført av uøvede veterinærstudenter.

(Received November 21, 1967). 